\title{
INTERNATIONAL BUSINESS BOOKS/PUBLICATIONS RECEIVED BETWEEN OCTOBER 1 AND DECEMBER 31, 1995
}

The Foreign Investment Debate: Opening Markets Abroad or Closing Markets at Home? Cynthia A. Beltz, editor. Washington, DC: The AEI Press, 1995 (hard) \$29.95 USD.

Industrial Policy and Semiconductors: Missing the Target. Andrew Dick. Washington, DC: The AEI Press, 1995 (soft) \$9.95 USD.

Industrial Restructuring and Trade Reorientation in Eastern Europe. Michael A. Landesmann and István P. Székely, editors. New York, NY: Cambridge University Press, 1995 (hard) \$59.95 USD.

Management for Privatization: Lessons from Industry and Public Service (Management Development Series No.32). J. Prokopenko, editor. Washington, DC: International Labor Office, 1995 (soft) \$33.75 USD.

Strategy, Innovation and Politics: A Process Approach. Stig Rée. Copenhagen, Denmark: Copenhagen Business School Press, 1995 (soft) DKK 194 incl. VAT.

Privatization: Implications for Corporate Culture Change. Alzira Salama. Brookfield, VT: Ashgate Publishing Company, 1995 (hard) \$55.95 USD.

Standards and APEC: An Action Agenda. John S. Wilson. Washington, DC: Institute for International Economics, 1995 (soft) \$12.95 USD.

Japanese Industry in the American South. Choong Soon Kim. New York, NY: Routledge, 1995 (soft) \$16.95 USD.

Strategic Management of the China Venture. Paul Steidlmeier. Westport, CT: Greenwood Publishing Group, Inc., 1995 (hard) \$65.00 USD.

Transforming Russian Enterprises: From State Control to Employee Ownership. John Logue, Sergey Plekhanov and John Simmons, editors. Westport, CT: Greenwood Publishing Group, Inc., 1995 (hard) \$65.00 USD.

Industrial Policy and Semiconductors: Missing the Target. Andrew Dick. Washington, DC: The AEI Press, 1995 (soft) \$9.95 USD.

International Trade in Goods and Factor Mobility. Kar-yiu Wong. Cambridge, MA: The MIT Press, 1995 (hard) $\$ 60.00$ USD.

Asia for Women on Business. Tracey Wilen and Patricia Wilen. Berkeley, CA: Stone Bridge Press, 1995 (soft) \$15.00 USD.

The Location of Foreign Direct Investment: Geographic and Business Approaches. Milford B. Green and Rod B. McNaughton, editors. Brookfield, VT: Ashgate Publishing Company, 1995 (hard) \$63.95 USD.

Global Business: Planning for Sales and Negotiations. Camille Schuster and Michael Copeland. Fort Worth, TX: Harcourt Brace College Publishers, 1996 (soft). 